\title{
Cultivation of Applied Foreign Language Talents in the Context of Hubei Free Trade Zone
}

\author{
Yun Zhang ${ }^{*}$ \\ Wenhua College, Wuhan, Hubei, 430074, China
}

ARTICLE INFO
Article history
Received: 25 January 2021
Revised: 2 February 2021
Accepted: 9 April 2021
Published Online: 16 April 2021

Keywords:

Hubei Free Trade Zone

Applied foreign language talents

The problems existing in the training

Countermeasures

\begin{abstract}
This paper explains that the construction and development of Hubei Free Trade Zone has brought opportunities for the employment of applied foreign language talents. It analyzes the problems existing in the training of foreign language majors in Hubei local undergraduate universities: the professional positioning is vague, the curriculum system is unreasonable; the teaching mode is relatively outdated and cannot stimulate students' interest in learning; the teaching skills are limited, and the teachers' practical ability is insufficient; Improper methods, insufficient attention to quality training, etc. In response to the above problems, the article puts forward ideas and countermeasures for training applied foreign language talents.
\end{abstract}

engineering design, cultural creativity, financial services, network services, artificial intelligence, and big data have gathered and developed significantly. Wuhan Area has introduced more than 50 major projects with a total investment of more than 200 billion yuan since its establishment. It has formed a pattern of five billion industry and two emerging industries. It has completed the whole industrial chain layout of "chip - display - intelligent terminal" and is building a world-class industrial cluster with an output value of over one trillion yuan. Xiangyang area has a complete new energy vehicle industry system. The annual output value of new energy vehicle enterprises

\footnotetext{
*Corresponding Author:

Zhang Jian,

Female, master's degree, associate professor,

Majoring in second language writing, intercultural communication;

E-mail: 499574362@qq.com.
}

Fund Project:

This paper is one of the achievements of 2020 Hubei Provincial Philosophy and Social Sciences Program— "Researches on the Training Paths of Applied Foreign Language Talents in Universities under the Background of Hubei Free Trade Zone Construction" (Project No.: 20G092). 
above designated size is more than 15 billion yuan, and it is striving to build itself into the capital of new energy vehicles in China. Since the listing of Yichang area, more than 4,700 new market entities have increased a year-onyear increase of nearly $40 \%$, with a total investment of more than 100 million yuan in 15 key projects.

It can be found that with the transformation and upgrading of the world economy, the export-oriented economy of Hubei Province has ushered in new opportunities of unprecedented development, which provides a large number of multi-language and multi-cultural foreign language professionals for the rapid development of the export-oriented economy of Hubei Province. As the scale of foreign language majors in Hubei universities are becoming immense, the applied foreign language talents is an urgent need to its leading Therefore, how to ensure the foreign language learners' continuous services for the local development and the construction are facing challenges and problems to be solved, and the future of foreign language teaching should serve the higher education internationalization, shouldering the historical mission of China to the world.

\section{Opportunities Brought by the Free Trade Zone to Hubei's Economic Development}

\subsection{To Bring Vitality to Economic Development}

Hubei Free Trade Pilot Zone includes urban industrial development and integration demonstration area, hightech industrial development zone and service free trade zone, with obvious advantages of policy superposition. The free trade zone is the city's most comprehensive commercial logistics distribution center with complete functions, but also with aerospace technology, intelligent robot research and development, advanced equipment manufacturing and other high-end manufacturing as well as convenient and efficient business logistics service system, industry and supporting services are extremely strong foundation. Since the establishment of Hubei Free Trade Zone, governments at all levels has flexibly transformed government functions, adjusted foreign trade and investment modes and reformed financial services. All kinds of reform measures have been warmly responded by foreign investors. According to statistics, "since the listing, the new enterprises in the pilot free trade zone have exceeded 30,000 , with a registered capital of 430 billion yuan. Up to now, more than 400 foreign invested enterprises have been set up in the Pilot Free Trade Zone in Hubei, with contracted foreign investment of 5.3 billion US dollars. The spillover effects of the pilot free trade zones are beginning to show, while the demand for foreign language talents is increasing." Obviously, the establishment of Hubei Free Trade Zone is bound to promote economic exchanges and technological cooperation among East Asia, even European and American countries.

\subsection{To Attract Talent and Create Opportunities for Employment Environment}

The current national policies strongly support investment attraction, Hubei Free Trade Zone will take advantage of the opportunity to continuously expand capacity, accelerate the development of Hubei economy. By expanding capacity, it will focus on high-tech manufacturing and advanced modern service industries, and realize the integration of upstream and downstream industrial chains and supporting service systems. Therefore, in the process of the construction and development of the free trade zone, there will be an urgent need for a large number of high-quality foreign language talents to meet the business needs of various industries in the industrial chain. In order to promote the introduction of talents, the Free Trade Zone has put forward more standardized criteria for the entry work permitting system of foreign employees and set up an efficient and convenient employee visa system while introducing the policy of human resources introduction. Correspondingly, when a large number of foreign talents are recruited to start businesses in Hubei, the need for cooperation and business communication is increased, which also provides a good opportunity for the employment of applied foreign language talents in local universities.

\section{Applied Foreign Language Talents Needed by the Free Trade Zone}

Hubei is the window of foreign economy and trade in the Central China, located in the Yangtze River economic circle and East Asia economic circle. The geographical position is convenient for attracting investment, the use of foreign capital to develop the inland economy. Labor resources are the key to economic development, which will inevitably bring the expansion of the demand for human resources. The establishment of Hubei Free Trade Zone has increased the demand for professional foreign language talents and technical talents. Therefore, foreign-funded enterprises in Hubei Free Trade Zone will provide more employment opportunities and good development space for college foreign language graduates.

\subsection{Quality Requirements}

The quality of applied foreign language talents plays a vital role in the development of the free trade zone. In order to meet the needs of economic exchange and coop- 
eration in the FTZ, the compound foreign language talents in the FTZ must have good professional ethics, rigorous professional quality and good cooperation and coordination ability.

The free trade zone often carries out trade cooperation with foreign enterprises. In the process of foreign trade transaction, there will be many intermediate links, such as logistics, insurance, customs declaration, commodity inspection, etc., which need to deal with different institutions and departments. Therefore, the employees should have strong communication and coordination ability, apt at optimizing interpersonal relationship and completing foreign trade business efficiently. In addition, the applied foreign language talents must have the spirit of innovation and strong learning ability. The FTA itself means institutional innovation, policy innovation and management innovation. The outstanding characteristics of applied talents are that they are rich in innovation ability, a broad vision, and constantly adapt to new competition and challenges, new rules and regulations and new business management concepts. Through continuous learning to adapt to the ever-changing environment, talents should do a good job in various foreign trade services, and constantly explore new trade growth points.

\subsection{Basic Skills}

Applied foreign language talents refer to those who have one or more skills in other aspects on the premise of foreign language proficiency. Foreign language applied talents in the free trade zone should have the following basic skills.

\subsubsection{Practical Foreign Language Skills}

To develop foreign trade business, it is required for the talents to be good at communicating with people from different countries or regions in cooperation negotiations, such as proficiency in listening, speaking, reading, writing and translating, etc. On the basis of application ability, talents should be able to smoothly read foreign trade correspondence, documents and files, as well as communicate freely in foreign negotiations.

\subsubsection{Computer Operating Skills}

Intelligent office must be the norm of future office, especially in foreign companies. In Hubei Liaoning Free Trade Zone, paperless intelligent office has almost reached the full coverage. Therefore, foreign language talents are required to skillfully operate basic office software, and use all kinds of foreign trade business application software to deal with problems in the work, and timely meet the di- versified trade needs of foreign trade customers.

\subsubsection{Professional Skills in International Trade}

In addition to foreign language, applied foreign language talents should also have knowledge and professional skills in other aspects, especially basic professional knowledge of international trade, and certain theoretical analysis ability. They should understand the current situation and direction of the development of contemporary international trade, and be familiar with the basic principles of WTO and international trade conventions. At the same time, it is necessary to understand the laws and regulations of the free trade zone, and be able to flexibly apply this knowledge to the development of the free trade zone. In addition, the free trade zone has established trade with many small countries, so there is also a lack of foreign trade talent in small languages.

\subsubsection{Skills in Other Fields.}

Talents should be able to use foreign language skillfully in telephone communication, email writing, document translation, business negotiation, and other professional knowledge and skills that are suitable for the business, such as finance, international trade, law, as well as financial management. It can be seen that applied foreign language talents should be versatile in foreign language translation, international trade knowledge, public relations and business negotiations, and official document writing.

\section{Problems in the Cultivation of Foreign Language Talents in Local Universities}

There are four problems in the process of cultivating applied foreign language talents in Hubei colleges and universities.

\subsection{The Vague Major Positioning and the Unrea- sonable Curriculum System}

At present, vague specialty orientation and unreasonable curriculum system are common problems in local application-oriented undergraduate colleges and universities. Although many colleges and universities emphasize the goal of cultivating applied talents, and also launch the education mode of combining double majors and double degrees, there are still two problems. There is a lack of integration between students' major courses and their elective secondary major courses. Even the traditional double degree courses lack compatibility in content, the two are simply listed together, and there is a lack of knowledge integration. The guidance of the business scope of the 
employment position is not clear. Without knowing the business content of the future job, most students will not choose a double major with a clear purpose. They just think that it is sufficient to master the foreign language as a language tool, as long as they simply choose the foreign language courses. As a result, colleges and universities only formally train application-oriented business foreign language talents, but the practical teaching program of ability cultivation has not been implemented, and traditional foreign language and literature are still the main teaching content. In the course, theory teaching occupies a large proportion, little energy is invested in applied practical ability, which causes the lacks of the cultivation of comprehensive quality and ability.

\subsection{The Outdated Teaching Mode and Failure to Stimulate Students' Learning Interest}

Nowadays, colleges and universities are encouraging students to speak in language learning, which is one of the key points of practicing foreign language application skills. However, the traditional foreign language teaching model is still mainly based on teachers' textbooks, and students only passively receive audiovisual and lack of initiative. In addition, even if students have established a certain language foundation in the foreign language courses, the content of the courses is still based on theoretical teaching. This will seriously restrict students' further studies in terms of practical ability and comprehensive quality training. In addition, the lack of guidance for students' independent career selection has severely restricted students' employment competitiveness and autonomous initiative. Classroom teaching should reduce the proportion of theoretical knowledge and increase the content of practical courses. For example, through the application of foreign language to conduct professional practice skills drills, and to continuously improve students' comprehensive quality and practical skills by simulating the business process of future work. Therefore, colleges and universities should find ways to provide correct employment guidance and increase students' practical ability training, so that students can clarify their future development direction and formulate study plans at the beginning of enrollment, which will be extremely important for graduates' employment.

\subsection{The Limited Teaching Skills and Insufficient Practical Ability of Teachers}

The teachers recruited by local colleges and universities are generally fresh graduates from normal colleges. After graduation, they directly take up their posts to teach, learn from the traditional teaching model, and teach di- rectly. However, colleges and universities sometimes neglect the assessment of professional practical ability in the assessment of teachers, and teachers have not updated their ideas in teaching methods. Therefore, there is a serious lack of professional practical experience, and the emphasis on theory and practice is also a weakness in their teaching. To cultivate interdisciplinary and application-oriented foreign language talents, only practitioners with rich working experience in foreign-funded enterprises or teachers with relevant industry qualifications can be qualified for teaching. This requires college teachers to master the ability and skills to cultivate practical talents to meet the current requirements of building applied undergraduate universities and cultivating applied undergraduate talents.

\subsection{Inappropriate Evaluation Methods and Insuf- ficient Attention to Quality Training}

Universities should no longer use performance as the only criterion for evaluating a student. It should be reconsidered how to evaluate students' comprehensive abilities comprehensively and objectively. Although the traditional examination is still a way to test student performance, it should not be solely based on test results as the only criterion for comprehensive evaluation of students. Foreign language graduates must not only pay attention to cultivating the basic skills of foreign language learning, but also strengthen the cultivation of professional and practical skills for future employment. Application-oriented universities are different from scientific research-oriented universities. The evaluation of graduates should first be based on social recognition and satisfaction. After entering the society, students need to deal with various problems in life and work, requiring them to have higher comprehensive qualities and abilities, including the ability to solve problems, adapt to the environment, communication skills, and public relations etiquette skills.

\section{The Mode and Countermeasures of Train- ing Applied Foreign Language Talents}

The mode of cultivating compound and application-oriented talents cannot simply be accomplished through the superposition of theoretical knowledge and ability machinery. Instead, knowledge and ability should be organically combined to integrate knowledge and ability, make them form a synergy and play a comprehensive role. Applied foreign language talents should also possess professional knowledge and skills in other industries such as information statistics, law, computer software, international trade, marketing and financial management. Facing 
the needs of the industrial development of Hubei Free Trade Zone, the training of relevant talents in colleges and universities needs to broaden thinking patterns and create a new type of applied foreign language talent education model.

\subsection{Talent Training Goal and the Direction of Ed- ucation Reform}

\subsubsection{Promote the Reform of Foreign Language Teaching Based on the National Development Strategy}

The "One Belt, One Road" initiative and the "Made in China 2025" strategy are promoting the digital, network, and intelligent upgrading of the manufacturing industry, accelerating all-round cooperation between China and countries in the world in related fields. At the same time, the introduction and use of imported equipment, negotiation of cooperation projects with multinational companies, professional research on the upstream and downstream international market industrial chain, release of new products or promotion and marketing ideas, etc., all require compound talents with foreign language as well as other professional skills. Colleges and universities should "seize the opportunity of 'Made in China 2025', and use the advantages of foreign language communication to broaden their own employment channels on the premise of updating professional knowledge and skills." For the direction of teaching reform, colleges and universities should tailor professional foreign language classes based on the strengths and academic performance of freshmen to cultivate top-notch talents suitable for national development strategies. Through the development of a four-year talent plan, it is necessary to comprehensively cultivate students' professional knowledge and gradually strengthen students' application ability in foreign language related majors, which means to strengthen the foundation of foreign language in junior schooling years, and cooperate with the professional training plan in senior schooling years, implement various practical foreign language professional teaching, and gradually promote the orderly and effective development of talent training plans.

\subsubsection{Rely on "Internet +" to Take Advantage of the Momentum}

"Internet +" is the most effective and most widely used network communication channel today. The development of free trade zone economies cannot be separated from the assistance of "Internet +", which has produced a great impact on foreign language compound talents who skillfully use this channel demand. The school's training of such talents should not only make students become "footmen" in international trade-related businesses, but also train smart users who can have Internet thinking and creatively integrate Internet platforms with traditional majors. The teaching team should extensively collect mature case materials, lead students to understand its value and significance and carry out relevant business training. In the practice process of the simulation project, we will guide students to cultivate their professional application consciousness of "Internet +". "Meanwhile, it can encourage social intermediary agencies, colleges, and various training institutions to participate in training and education, through seminars, academic exchanges, job training, etc., to carry out targeted services to ensure the continuous improvement of personnel skills and quality.

\subsection{Carefully Design the Curriculum System and Innovate Evaluation Methods}

\subsubsection{Broaden the Professional Scope and Opti- mize the Curriculum System}

Curriculum system is the concrete manifestation and fundamental way to achieve the goal of talent training. The school should carry out posts work content research according to the needs of regional construction and development, fully understand the knowledge and ability requirements of the talents needed by the company. In addition, due to the differences in various industries in the Hubei Free Trade Zone, the professional and comprehensive quality requirements of the required talents are also different. The curriculum content should be set through scientific analysis, combined with the characteristics of the free trade zone, and a reasonable curriculum teaching system should be constructed. In addition to basic foreign language courses, professional business ability training courses are added. Colleges and universities should implement the credit system assessment in professional courses, actively guide students to carry out double majors, and cultivate students' concept of "foreign language application ability + comprehensive quality + other professional business ability". Each professional course should use foreign language as the language expressing form of textbooks when teaching, and at the beginning of enrollment, the employment guidance department of college students should conduct classified guidance and explanation of employment work content. In this way, students majoring in foreign languages can clarify the application direction of the second major in advance. In their course plan, it should set up courses in accordance with the employment requirements and job standards of enterprises as well as the core courses of business English. This training model 
not only emphasizes the cultivation of students' foreign language listening, speaking, reading, writing, and translation skills, but also the training of students' professional job skills, so that students can meet the needs of enterprises, and focus on training "to be able to analyze, understand marketing, sophisticated technology, and be good at combat", etc. The comprehensive abilities that compound talents should possess fully reflect the educational purpose and significance of applied universities.

\subsubsection{Optimize the Evaluation Method and Pro- mote Learning by Competition}

During the school period, students' excellent performance is the criterion for evaluating their excellence, and after entering the society, employers are evaluated by their comprehensive ability level. Schools should take the students' comprehensive quality and ability as the main weight for key assessment. It is too one-sided to evaluate the merits and demerits only based on the theoretical knowledge test results. In the teaching process, we must implement the concept of teaching students in accordance with their aptitude and direction, scientifically design classroom teaching plans, incorporate practical ability and comprehensive quality training in the theoretical teaching process, give full play to students' autonomous self-learning initiative, and enable students to turn their foreign language skills into their own ability, which is integrated with the practicality of professional courses. For instance, teachers can adopt vivid and flexible teaching methods such as teacher-student interaction, corporate case demonstrations, and micro-classes to motivate students' interest in learning. Students participate in various English competitions, such as writing competitions, reading competitions, oral competitions, etc. Throughout various English competitions, the number of students in our province who can enter the national finals is relatively promising, indicating that the English ability of college students in our province is relatively high. Therefore, colleges and universities in our province should make use of student second-class activities to carry out various foreign language competitions. This can not only improve students' English ability and promote learning through competitions, but also enable students to understand Western culture through competitions, which is conducive to cultural exchanges.

\subsection{Carry out School-Enterprise Cooperation and Fully Implement Practical Teaching}

\subsubsection{Speed up the Training of Teachers and Build A "Dual-Teacher Dual-Ability" Team}

High-quality faculty is the key to determining the lev- el of running a school. Colleges and universities should establish evaluation standards for excellent teachers with dual teaching abilities, and score according to the standards, set up evaluation elements for professional title promotion, increase corresponding salaries, and encourage teachers to take corresponding majors practical qualification certificate, etc. Teachers who pass vocational examinations and improve relevant theoretical knowledge can not only strengthen their own professional theoretical standards, but also combine with corporate practical experience, and eventually become excellent "dual-teacher dual-ability" teachers, which can provide students with more professional education guidance. Through the scientific classification assessment of the teacher evaluation system, teachers can be divided into three categories: theoretical teaching, practical teaching, and scientific research teaching. The school stipulates corresponding basic teaching hours. Teachers can choose to focus on teaching or professional practice every year according to their own types, reducing the excessive scientific research tasks of practical teachers. In addition, before the start of each semester, teachers can be arranged to work in companies. Teachers conduct research on the combination of theory and practice in companies, accumulate experience, and collect targeted teaching cases. During this period, teachers compare the actual process of the business with the textbook theory, and after their own understanding and digestion, they scientifically formulate the school year teaching plan and improve the teaching plan. After returning to classes, teachers can edit their practical experience into teaching case micro-classes, and carry out online and offline assisted teaching to increase students' interest in learning and effectively improve the quality of teaching. At the same time, the school can hire some elites in the industry to impart valuable experience and advices to the school, or recruit outstanding talents in the industry and build a team of teachers and consultants with strong practical ability to strengthen the teaching team.

\subsubsection{Reform the Traditional Teaching Model and Promote School-Enterprise Cooperation}

Elites trained in colleges and universities will devote themselves to construction work in all walks of life after graduation. Universities can do a good job of service for students' graduation internships and employment, and build bridges between graduates and enterprises. For this reason, schools should find ways to build cooperation mechanisms with enterprises to create a practical environment for students. This is not only conducive to improving students' practical ability, but also to prepare human resource reserves for enterprises in advance, and build a 
new model of school-enterprise cooperation in education reform. As a human resources training base, applied undergraduate colleges and universities should keep pace with the times, discard outdated talent training methods, actively explore talent training models that meet the needs of regional development, seek government support and assistance, strengthen cooperation with enterprises, and cultivate to produce high-quality and compound business foreign language talents who can help the free trade zone to develop. There are many reliable modes of school-enterprise cooperation, such as joint school running by enterprises, inviting industry elites to teach, hiring enterprise expert consultants, organizing a multi-professional teacher team to enter the company for investigation, establishing practical training teaching pilot classes, changing traditional teaching thinking, and enriching teachers' practice ability, etc. Although these school-enterprise cooperation models are not yet mature, on the one hand, they can strengthen the construction of teaching teams, and on the other hand, they can build a cooperation platform between school and enterprise to help each other and provide companies with high-quality compound foreign language talents. Only by allowing enterprises fully realize the benefit of school-enterprise cooperation and the guarantee of human resources can they promote school-enterprise cooperation to all walks of life.

\section{Conclusion}

With the increasing demand for foreign language talents in society, foreign languages have become a "major specialty". For local applied undergraduate universities, if the students are not needed by society, they will be eliminated by society and the times in the long run. In the exploration of cultivating innovative foreign language talents, we should update our educational concepts, be brave to innovate educational practices, and expand operational ideas. In view of the widespread problem of the stratification and lack of differentiation of innovative talents in foreign language schools of applied universities, it is necessary to set up long-term effective cooperation mechanism. The teaching mode reform must be implemented early, and the planning of the future foreign language application education method must be deployed as soon as possible. It is our responsibility to serve local construction, cultivate the available talents urgently needed in the free trade zone, increase employment, and benefit the society. Combining Hubei's local economic characteristics, it is inevitable to seek an excellent human resource training plan that is in line with the development of Hubei Free Trade Zone, develop teaching models that meet the needs of the new era, and enhance the quality of classroom teaching.
According to the demerits of the current foreign language talent training model, effective countermeasures should be proposed, such as changing the curriculum structure system, innovating teaching methods, upgrading professional compatibility, advocating school-enterprise cooperation, and building a dual-teacher dual-capable teaching team. Teachers should be encouraged to leave their posts to strengthen practice, and scientifically optimize evaluation standards. It is believed that after these reform measures are put in place, they will be able to cultivate applied foreign language talents suitable for the development of Hubei Free Trade Zone.

\section{References}

[1] An Fengcun, Zhao Lei. On foreign language education policy in China under the background of "One Belt And One Road" [J]. Journal of Yanbian University (Social Sciences), 2017(4):26-32.

[2] Du Qian. Current Situation Analysis and Cultivation Strategies of College Students' Intercultural Communication Competence under the Background of "One Belt And One Road" Strategy [J]. Journal of Jilin Radio and TV University, 2019(9):15-18.

[3] Fu Yuanyuan. A Preliminary Study on the Training of Foreign Language Talents with Intercultural Communication Competence under the Background of "One Belt And One Road" [J]. Theoretical Observation, 2019(4).

[4] Guan Zhipeng. Achievements, Problems and Suggestions of Reform and Innovation in Hubei Free Trade Zone $[\mathrm{J}]$. Administrative Asset and Finance,2018(15):41-42.

[5] Hao Shouyi, Cheng Dong. Reconstruction of regional cooperation mechanism under the strategic background of the Yangtze River Economic Belt [J]. Reform, 2015(3).

[6] Hu Zhonghai. Solidly promoting the construction of Hubei Free Trade Zone [J]. Policy,2016(12):29-32.

[7] Huang Wei. New mission of college English courses -- serving the "One Belt And One Road" strategic talent training $[\mathrm{J}]$. College English Teaching and Research,2019(2):109-115.

[8] Huang Ying, Li Lin. Study on the training of applied economic and trade talents to meet the needs of $\mathrm{Hu}-$ bei Pilot Free Trade Zone [J]. Journal of Huanggang Normal University, 2019(1):124-1276. (in Chinese)

[9] Li Cong, Wei Yuzhen, Wu Lin. An Analysis and Research on the English Translation of Company Names in Wuhan Free Trade Zone [J]. English Teacher, 2019(18):19-21.

[10] Shen Qi. The Four Ttasks of the "Belt and Road" 
Foreign Language Education Plan [J]. Contemporary Foreign Language Studies, 2019(1).

[11] Song Wen, Huang Ying, Pan Lingxiao. Research on Cross-border Trade Talents Training under the Background of Hubei Free Trade Zone -- Taking Business Negotiation Course as an Example [J]. Journal of Science, Technology and Economics, 2019,27(13):121122.

[12] WANG Hui, XIA Jinling. Research on "One Belt And One Road" non-lingua franca talents training and market demand in universities [J]. Audio-visual teaching of foreign languages, 2019(2).

[13] Wang Xuemei. Reflections on the development planning of foreign language discipline from the perspective of national strategy [J]. Foreign Languages in China,2017(5):29-37. (in Chinese)

[14] Wang Yanyan. Establishment of Training Model of Local Colleges and Universities for the Construction of Shanghai Free Trade Zone[J]. Education Development Research, 2013(21):69-72. (in Chinese)

[15] Wang Zhuo. Construction of Three-dimension Foreign Language Education in Colleges and Universities under the Background of One Belt And One Road [J]. Foreign Language Teaching in Shandong,
2019(5).

[16] Wei Junying, Chen Ren. Research on the Training of International Economic and Trade Talents in Local Universities under the Background of the Construction of Hubei Pilot Free Trade Zone [J]. Journal of Agricultural Economics and Science,2017(9):280-282.

[17] Yang Jirui, Luo Zhigao. Thinking and countermeasures of "One Belt And One Road" construction and strategic coordination of Yangtze River Economic Belt [J]. Economic Review, 2017(12).

[18] Guidance on the construction of China's new economic support belt based on the Yangtze River [R]. National Development and Reform Commission, 2013(9).

[19] Zhong Weihe, Wang Weiwei. Reform and development of foreign language education in Chinese colleges and universities under the background of the new era $[\mathrm{J}]$. Shandong Foreign Language Teaching(in Chinese),2018(3):42-49.

[20] Zhu Tao Ying. Cultivation of Competent Foreign Language Talents in the Context of One Belt And One Road [J]. Chinese Journal,2016(6). 